\title{
Role of Internet Accessibility in Reducing the Poverty rates in Java; a Spatial Approach
}

\author{
${ }^{* 1}$ Hidayat, Andhy, ${ }^{2}$ Prasetyia, Ferry \& ${ }^{3}$ Pangestuty, Farah \\ "1 Perekonomian Sekretariat Daerah Kabupaten Pasuruan, Pasuruan, Indonesia \\ ${ }^{2}$ Faculty of Economic and Business, Universitas Brawijaya, Malang, Indonesia \\ ${ }^{3}$ Faculty of Economic and Business, Universitas Brawijaya, Malang, Indonesia
}

Note: * Indicates corresponding author

\begin{tabular}{ll}
\hline \hline ARTICLE DETAILS & ABSTRACT \\
\cline { 1 - 2 } $\begin{array}{l}\text { Article History } \\
\text { Published Online: publisher use } \\
\text { only }\end{array}$ & $\begin{array}{l}\text { The poverty reduction rate in Java was considered very low, thus } \\
\text { requiring new strategies and policies, such as the improvement of } \\
\text { internet accessibility. This study, using the 2018 National Socio- }\end{array}$ \\
$\begin{array}{ll}\text { Keywords } \\
\text { Poverty, Internet Accessibility } \\
\text { Spatial Spillover Effect, Spatial } \\
\text { Approach, Susenas }\end{array}$ & $\begin{array}{l}\text { internet accessibility to reduce poverty rates in Java through a } \\
\text { spatial approach. The results showed that internet accessibility } \\
\text { had a significant effect on the reduction of poverty rates in Java. It } \\
\text { also found that the poverty rates in an area in Java were influenced } \\
\text { by the types of works of household heads in the same location and } \\
\text { the poverty rates in neighboring areas (spatial spillover effects). } \\
\text { "Corresponding Author } \\
\text { Email: undhee.22@gmail.com }\end{array}$ \\
$\begin{array}{l}\text { This study recommended that the Government, in reducing } \\
\text { poverty rates, focuses on providing internet infrastructure and, } \\
\text { more, on spatial aspects. }\end{array}$ \\
\hline \hline
\end{tabular}

\section{Introduction}

The issue of poverty is still the heaviest and is always seen as a serious problem for all countries, especially developing countries (Peters et al. 2008). According to the World Bank, there were approximately 736 million poor people, or 10 percent of the world's population, scattered throughout the world in 2018 (Alfrojems dan Anugrahini 2019). Cobbinah and Black (2013) argued that global poverty still occurred because there were still many people in the world whose economic statuses were still below a decent standard of living.

The World Bank, for 2030, has 2 (two) main targets in overcoming the problem of poverty globally: first, to reduce the number of the population living on less than 1.90 dollars a day and, secondly, to increase the income of as many as 40 percent of the poorest population (World Bank 2018). To support the success of these two main targets, in September 2015, leaders of countries in the world agreed to the Sustainable Development Goals (SDGs) program which took place in New York (Dhahri dan Omr 2020), as a continuation program from the previous program, the Millennium Development Goals (MDGs). The success of the MDGs program was hoped to repeat in the SDGs program in dealing with poverty problems (Lampert dan Papadongonas 2016).

Faculty of Economics and Business, Universitas Brawijaya
Indonesia as a developing country sees that poverty has been a problem since its founding era. When viewed from the division of regions into villages and cities, poverty in Indonesia is occurring mostly in rural areas (Hasibuan et al. 2019). In 2018, the largest number of poor people in Indonesia were in the islands of Sumatra and Java (Bappenas 2018), so reducing the poverty rate in Java is very strategic.

Three factors underlie why poverty reduction in Java is so strategic. The first, as in Figure 1 , is that the average poverty reduction rate every year in Java and the National is very slow because it does not match the target rate of poverty reduction as stated in the 2014-2019 National Medium Term Development Plan (RPJMN). The second, based on Chart 2, is that the population in Java is quite large, which is more than half of the total population of Indonesia. Meanwhile, the third one is that there is a strong correlation between the poverty rate in Java and that in the National as shown in Chart 3 . Therefore, accelerating the poverty reduction rate in Java will certainly have an impact on that nationally.

According to Haughton and Khandker (2012), the cause of poverty at the regional level is low accessibility, which is one of the spatial dimensions of easy access between one region 
and another (Ahlström et al. 2011). Related to economic factors, poverty and production patterns are of the accessibility in question. Accessibility constraints tend to deepen sociospatial inequality leading to poverty (Lucas et al. 2016). According to Benevenuto and Caulfield (2020), the poverty rate of a region is caused by a lack of access to basic facilities. Internet accessibility is one of the accesses to basic facilities that affect poverty rates (Ruhyana dan Essa 2020).

Lack of internet access in providing information to the poor causes poverty (Widiastuti 2014). According to Khoirunnisa and Budiarti (2019), the poor have limited access to information quickly in improving their quality of life. They tend to be late in getting information relating to the availability of business opportunities. With this limited information, it is difficult for them to change their economy in terms of increasing income (Azzasyofia dan Adi 2017).

Equitable information and communication technology is needed to accelerate poverty alleviation through the exchange of information quickly and efficiently (Widiastuti 2014). Utilization of Information and Communication Technology (ICT) through internet access is key in empowering people whose economic statuses are still below a decent standard of living (Tisdell 2017). According to the World Bank (2003), ICT through internet access can increase access to markets, increase the competitiveness of poor individuals, and make it easier for people to gain access to create new jobs.

Several previous studies, such as those conducted by Risner and Gadhavi (2016), Rivera and Mora (2020), Alderete (2019), and Lin et al. (2017), showed that internet accessibility plays a major role in reducing the poverty rate of a region. However, these studies did not consider spatial aspects. Analysis of the role of internet accessibility in reducing poverty rates through a spatial approach was then very important because accessibility was one of the spatial dimensions (Ahlström et al. 2011). Based on this reason, this study aimed to update previous studies in analyzing the role of internet accessibility in reducing poverty in Java through a spatial approach.

\section{Literature Review \\ Poverty-causing Factors}

Poverty means deprivation of welfare (Haughton dan Khandker 2012). Sen (1985) stated that poverty is a lost opportunity to gain basic capabilities. Robert Chambers (1983) has another view: poverty is a cluster of unfavorable conditions such as physical weakness, vulnerability to shocks, isolation, powerlessness, and poverty itself, which cause a person to be trapped and difficult to get out of it.

Meanwhile, the Central Statistics Agency (2016) defined the poor as people who have an average expenditure per capita per month below the poverty line (PL), both for food and non-food expenditures. The calculation approach carried out by the Central Statistics Agency (BPS) was through a monetary approach through the poverty line. The poverty line value used referred to the minimum need of $2,100 \mathrm{kcal}$ per capita per day plus the minimum non-food needs as individual basic needs, including basic needs for housing, clothing, schools, transportation, and other basic household and individual needs. The value of the expenditure (in Rupiah) to meet the minimum basic needs for food and non-food is called the Poverty Line (BPS 2007)

The causes of poverty consist of several factors. According to Kuncoro (2006), poverty arises from underdevelopment, market imperfections, and lack of capital, all of which cause low productivity. Low productivity results in low income they receive; low income will imply low savings and investment; low investment will result in underdevelopment; and so on.

Haughton \& Khandker (2009) provided another view that the causes of poverty are caused by 4 (four) types of characteristics: (1) Individual Characteristics, such as age, education, employment status, health status, and ethnicity; (2) Household characteristics, such as dependency ratio, number of household members, asset ownership, type of work, and work structure; (3) Community Characteristics, such as infrastructure, land distribution, and social capital; and (4) Regional Characteristics, such as isolation (poor access to markets and services), resource base, weather, and inequality.

\section{The Role of Internet Accessibility Reducing Poverty rates}

Low accessibility causes regional poverty (Haughton dan Khandker 2009). According to Ahlström et al., (2011), accessibility is a spatial dimension of easy access to basic facilities from one region to another. One of the accessibility to basic facilities is the use of internet access (Ruhyana dan Essa 2020).

Until this paper was written, internet users in the world reached nearly 3.2 billion people, $42,258,824$ of whom were in Indonesia (Azzasyofia dan Adi 2017). In this era of globalization, information and communication technology (ICT) through the use of internet access plays an important role in economic activity (Wardhana et al. 2020). Besides, another 


\section{Role of Internet Accessibility in Reducing the Poverty rates in Java; a Spatial Approach}

positive impact of internet access can reduce the poverty rate of a region (Ruhyana dan Essa 2020).

Along with the growth of internet access in the world, the internet has the function of providing information and communication quickly (Maurseth 2018). It has made access to information easier and helped integrate human resources whose production chains and productivity increase in remote areas and conventional industries are underutilized (Lin et al. 2017). Information and communication technology through the use of internet access creates opportunities for rapid economic activity (Choshin dan Ghaffari 2017).

There is a relationship between internet accessibility and poverty. According to Rivera and Mora (2020), lower internet accessibility will lead to high levels of regional poverty. Poor areas are caused by the lack of use of internet access (Widiastuti 2014). The poor have limited access to information regarding the availability of business opportunities to improve their quality of life (Khoirunnisa dan Budiarti 2019). In conditions of limited access to this information, the poor will find it difficult to increase their income so that they are trapped in a cycle of poverty (Azzasyofia dan Adi 2017).

Doong and Ho (2012) stated that proper use of internet access can reduce poverty and improve the quality of human life. Also, the results of research conducted by Litan and Rivlin (2001) emphasized that the role of the internet can increase productivity. According to Yekini et al. (2012), the use of the internet has a positive impact on the poverty reduction rate through the provision of effective and competitive Information and Communication Technology (ICT) infrastructure. The role of ICT through the use of internet access is the key in empowering people whose positions are still below a decent standard of living (Tisdell 2017). In addition, according to the World Bank (2003), internet access can increase access to markets, increase the competitiveness of poor individuals, and make it easier for people to gain access to create new jobs.

The extreme impact of internet connectivity is proven to reduce poverty in Bangladesh in poverty alleviation programs (Risner dan Gadhavi 2015). Besides, Sujarwoto and Tampubolon (2016) stated that spatial inequality is related to internet inequality. Their findings suggested that the internet deepens inequality and poverty. According to Alderete (2019), at present, the internet is often used more by the community as a development tool that strengthens social and commercial interactions by providing more efficient access to various opportunities, which in turn can turn it into an important instrument for increasing employment opportunities, increase education levels, and increase income. This mechanism can help in fighting poverty.

\section{Method}

This study used data based on the National Socio-Economic Survey (SUSENAS) of March 2018 in 119 regencies/cities in Java. The data were cross-sectional and longitudinal data, namely data of one or more variables collected at the same time at the district/city level. The sample selection method in Susenas was a two stage-one phase stratified sampling method with district/city estimates.

The methods of analysis in this research were descriptive analysis and verification analysis. The descriptive approach was used to explain or describe the facts that occurred in each of the variables studied, while the verification approach was used to determine the causality relationship between variables through a test.

The response variable in this study was the poverty rate (Pov) which was measured through per capita expenditure below the poverty line $(\mathrm{PL})$ in each district/city in Java in 2018. People with per capita expenditures less than the poverty line were classified as poor. The predictor variables used were 5 (five) variables: the education level of the head of the household (Edu_HHH), the type of work of the head of the household (Job_HHH), the size of the household (Size_HH), internet accessibility (Acc_Net), and accessibility of People's Business Credit (Acc_KUR). Each response variable and predictor variable used was aggregated in each district/city in Java. The 2018 Susenas data sampling conducted by the Central Statistics Agency (BPS) was assumed to be evenly distributed in each region. The details and definitions of these variables can be seen in Table 1.

This study used a spatial regression model that was formed from the development of the Ordinary Least Squares (OLS) model for cross-sectional data (Draper dan Smith 1998). The spatial regression model has three types of spatial interactions that describe the dependability of one location to another including interactions between response variables, interactions between response variables at a location influenced by predictor variables for neighboring locations, and spatial interactions between error terms (Elhorst 2014). These three types can be constructed as in Equation 1. 


$$
\widehat{Y}=\rho W Y+\beta X+\theta W X+\lambda W \mu+\varepsilon,
$$

where $\hat{Y}$ is a response variable/poverty rate in Java $(119 \times 1), X$ is a response variable $(5 \times 1)$, $W$ is a spatial weighted matrix measuring $119 x$ 119, $\rho$ is lag spatial coefficient of response variable, $\theta$ is lag spatial coefficient of predictor variable, $\lambda$ is autoregressive spatial coefficient on error, while $\mu$ and $\varepsilon$ are the regression error.

The analysis of this spatial regression model will be divided into 4 (four) stages as follows:

1) Construction of Spatial Weighted Matrix

2) Spatial Autocorrelation Test (Moran I)

3) Lagrange Multiplier Test (LM)

4) Best Model Selection

\section{Analysis and Discussion Analysis Results Descriptive statistics}

In Table 2, the results of descriptive statistics show the number of samples used in this study, namely 119 districts/cities in Java, including the lowest value (Min), highest value (Max), mean value (Mean), and standard deviation for each variable used. The variables in this study were the level of education of the head of the household (Edu), the type of work of the head of the household (Job), internet accessibility (Acc_Net), and accessibility of People's Business Credit (Acc KUR) as predictor variables for testing poverty rates (Pov) in Java.

\section{Results of the Spatial Autocorrelation Test (Moran I)}

The first stage in analyzing spatial regression was done by testing the spatial autocorrelation using Moran I. Spatial autocorrelation is a spatial correlation: the dependence between two observations at different locations. In general, observations at locations that are close together have a correlation higher than, or similar to, observations that are far from each other (Fitriani dan Efendi 2019).

The Moran's Index ranges from -1 to 1 . The positive value of the Moran's Index (l>0) indicates a positive spatial autocorrelation, which means that the close observation locations have similarities, while the negative Moran's Index value $(I<0)$ indicates that there is negative spatial autocorrelation, which means that observations at an adjacent location tend to be different. Meanwhile, Moran's Index of zero (I $=0)$ indicates that there is no spatial autocorrelation in the data (Anselin 1988).

The statistical results of the Moran I test in Table 3 from data processing using $R$ Studio found that there was autocorrelation in the response variable and predictor variables with Moran I value $\neq 0$ and $p$-value $<0.01$. Therefore, $H_{0}$ was rejected (rejecting the OLS regression model). The Lagrange Multiplier test in spatial regression modeling was then carried out.

\section{Lagrange Multiplier Test Results}

The next test was the Lagrange Multiplier (LM) test as the basis for selecting the appropriate spatial regression model (Fitriani dan Efendi 2019). This test also analyzed the significance of Lagrange Multiplier Lag and Lagrange Multiplier Error to select the right spatial regression model.

The Lagrange Multiplier test in Table 4 resulted in significant LM Lag and LM Error with $p$-value $<0.01$. If the LM Lag and LM Error are both significant, testing for deeper spatial effects will only be carried out on both parameters lag and error using the Robust Lagrange Multiplier, which will show that the parameter error is significant if the $p$-value is $<0.1$, and is not significant if the $p$-value is $>0.1$. So, the suitable model is Lagrange Multiplier Error, which indicates that there is a dependency on the error so that the spatial regression modeling of error is carried out. (Elhorst 2014).

\section{Best Model Selection}

The stages after performing the Lagrange Multiplier test were doing the Spatial Autoregressive Confused (SAC), Spatial Error Model (SEM), and Spatial Durbin Error Model (SDEM) regressions modeling, which were then followed by the selection of the best model. According to Fitriani and Efendi (2019) choosing the best model is an evaluation process of the model to find out how big the chance is that each model formed is following the data. AIC (Akaike's Information Criterion) is one of the criteria used in selecting the best model. The model with AIC is better.

Table 5 shows the Spatial Autoregressive Confused (SAC) regression model to be the best model with the smallest AIC value than other regression models. The results of the SAC model equation are formed according to Equation 2.

$$
\begin{aligned}
& P o v=0,1544 \mathrm{Edu}_{-} \mathrm{HHH}+ \\
& \text { 0,077 Job_HHH + 1,866 Size } \mathrm{JHH}_{-} \\
& \text {0,167 Acc } \_ \text {Net }+ \text { 0,001 Acc_KUR - } \\
& 0.601 W P o v+0,817 W \mu+\varepsilon \quad \ldots \ldots \ldots(2)
\end{aligned}
$$

where Pov is poverty rate, Edu_HHH is the variable level of education of the head of the household, Job_HHH is the variable type of household head job, Size_HH is the variable household size, $A c c_{-} N e t$ is the variabel internet 


\section{Role of Internet Accessibility in Reducing the Poverty rates in Java; a Spatial Approach}

accessibility, $\quad A c c_{-} K U R$ is the variable accessibility of People's Business Credit, $W$ is a spatial weighted matrix measuring $119 \times 119$, and $\mu$ is the regression error.

\section{Discussion \\ Poverty Condition in Java in 2018}

Java is one of the largest islands in Indonesia, located in the southern part. It is surrounded by waters, in the form of oceans, seas, and straits. Geographically, it is directly adjacent to the Indian Ocean to the south, the Bali Strait to the east, the Sunda Strait to the west, and the Java Sea to the north. It has an area of approximately $126,700 \mathrm{~km}^{2}$ with a population of about $149,635,600$ people, which makes it the island with the largest population and the most populous in Indonesia. It has 119 cities/regencies divided into 6 provinces, namely DKI Jakarta Province, Jawa Barat Province, Banten Province, Jawa Tengah Province, Yogyakarta Special Region, and Jawa Timur Province (BPS 2019).

The problems in Java are very complex, one of which is the problem of poverty. According to Bappenas (Bappenas 2018), the largest number of poor people was in Java in 2018. The approach to calculating the poverty rate in Java was based on the Susenas Survey. The determination of the poor was carried out based on the poverty line calculated based on the fulfillment of both food and non-food needs. The poverty line is equivalent to meeting 2100 calories per capita (BPS 2019). Table 2 shows the average poverty rate in Java of 9.62 percent. When viewed from the poverty rate of each district/city, Sampang Regency in Jawa Timur Province had the highest poverty rate, while Tangerang Selatan City, which is in Banten Province, had the lowest poverty rate.

Based on Figure 1, the poverty rate in Java was divided into 3 quartiles: high, medium, and low poverty rates. The darker the color on the map defines the higher the poverty rate and vice versa. In Figure 1, 40 cities/regencies had high poverty rates, 39 districts/cities had moderate poverty rates, and 40 districts/cities had low poverty rates. However, the poverty rate in Java tended to be clustered in several regions. The central part of Java Island, which includes the Provinces of DKI Jakarta, Banten, and Jawa Barat, had an average low poverty rate when compared to the central and eastern parts of Java.

Several factors were found influencing the poverty rate in Java. Table 5 shows that the type of work of the head of the household in agriculture (job_HHH) and the level of internet accessibility (Acc_Net) had a significant effect on the poverty rate in Java. In addition, the poverty rate in Java was also influenced by poverty in neighboring areas. This was evidenced by the significant value of $\rho$ (rho) of 0.601 . According to Fitriani and Efendi (2019), the SAC model is a model that assumes that apart from being influenced by predictor variables at the same location, the response variable is also influenced by the average value of the response variable at neighboring locations and other explanatory variables.

The form of the SAC model relationship in this study described the spatial spillover effect phenomenon on poverty in Java Island. The poverty of an area in Java Island was not only influenced by the type of work of the head of the household and the level of internet accessibility in the same location but was also influenced by poverty in neighboring areas (inter-regional poverty linkages). This finding was in line with that researched by Rupasingha and Goetz (2003), that changes in poverty are actually influenced by poverty in neighboring areas. The poverty reduction impact of an area has a spillover effect in a series of adjacent areas (Crandall dan Weber 2004).

Several studies found sufficient evidence of a geographic concentration of poverty: poor households tend to live in areas where the majority of the population is poor (Khan et al. 2006). Areas that have high poverty rates are due to low accessibility (Haughton dan Khandker 2009). According to Ahlström et al. (2011), accessibility is one of the spatial dimensions of easy access from one region to another. It is related to economic factors such as poverty and production patterns. Its constraints tend to deepen socio-spatial inequality leading to poverty (Lucas et al. 2016). According to Benevenuto and Caulfield (2020), the poverty rate of a region is caused by a lack of access to basic facilities.

\section{The Role of Internet Accessibility in Reducing the Poverty rates in Java Island}

In this era of globalization, the internet has become a basic necessity. The development of internet network technology has changed the paradigm to that getting information and communicating is no longer limited by the dimensions of space and time (Setiyani 2010). According to Silvana et al. (2019), the use of the internet is a solution to meet the individual needs for information for work, research, spiritual satisfaction, education, and others.

During its development, the use of the internet in the world has increased drastically every year (Flanagin dan Metzger 2001). More than half of the world's population are internet 
users (Azzasyofia dan Adi 2017). Based on Table 2, the average level of internet accessibility in Java is 46.06 percent. The level of internet accessibility in Lumajang Regency has the lowest accessibility at 26.83 percent. Meanwhile, Tangerang Selatan City has the highest level of internet accessibility at 73.47 percent. When viewed by region as shown in Figure 2, the western parts of Java Island such as DKI Jakarta, Jawa Barat, and Banten Provinces have a higher level of internet accessibility than those in the central and eastern parts of Java Island such as Jawa Tengah, DI Yogyakarta, and Jawa Timur.

The larger number of internet users has a positive impact on increasing economic activity (Wardhana et al. 2020). In addition, the use of the internet also has an impact on reducing poverty rates (Ruhyana dan Essa 2020). Based on Equation 2, the effect of internet accessibility (Acc_Net) can significantly reduce the poverty rate in Java. This means that every 1 percent increase in internet accessibility will reduce the poverty rate in Java by 0.167 percent. These results are in line with research conducted by Risner and Gadhavi (2015), Sujarwoto and Tampubolon (2016), Rivera and Mora (2020), Alderete (2019) and Lin et al. (2017), that internet accessibility plays a very important role in reducing the poverty rate of a region.

One of the characteristics of the poor is the lack of use of internet access to get information (Widiastuti 2014). Figure 3 shows the ability of the poor in Java Island to access the internet by 5.03 percent; the rest is accessed by non-poor people. The low level of the poor in accessing the internet has resulted in limited information regarding the availability of business opportunities to improve their quality of life (Khoirunnisa dan Budiarti 2019). In this condition, the poor cannot increase their income and then are carried away by poverty (Azzasyofia dan Adi 2017).

The quality of life can be improved by utilizing internet access (Doong dan Ho 2012). According to World Bank (2003), internet access can increase access to markets, increase the competitiveness of poor individuals, and make it easier for people to gain access to create new jobs. It also plays a role in creating opportunities for rapid economic activity (Choshin dan Ghaffari 2017). In addition, the internet plays a role in helping integrate human resources whose production chains and increasing productivity in various remote areas are underutilized (Lin et al. 2017).

A study conducted by Galperin (2017) found a major contribution to the influence of the internet in fighting poverty in several developing countries. The internet connectivity has a significant role of reducing poverty in Bangladesh in poverty alleviation programs (Risner dan Gadhavi 2015). Inequality of internet connectivity and internet prices has an effect on poverty rates (Rivera dan Mora 2020). According to Sujarwoto andTampubolon (2016), spatial inequality related to the gap in internet connectivity will deepen inequality and poverty. The results of research conducted by Park (2017) showed that in general rural areas have higher internet costs and poor internet coverage. This condition creates losses and digital gap for rural communities who cannot access the benefits of the products and services provided by ICT (Deursen dan Dijk 2019). Apart from the imbalance of internet connectivity and internet prices, the benefits of the internet will be even greater if it is supported by individual skills in navigating the internet (Galperin 2017; Deursen dan Dijk 2019) .

Based on these findings, implicatively, the government strives to reduce poverty by focusing on increasing the accessibility of technology, information, and communication infrastructure, especially internet accessibility. Efforts can be made by providing an effective, competitive, and targeted public internet infrastructure. Equitable internet access in each region is needed to avoid unequal internet access between regions. Besides, the government provides education in the form of internet utilization training for communities in isolated village areas to improve individual skills in navigating the internet.

\section{Conclusion and Recommendation}

Based on the results of the study, the following points can be concluded:

1. The poverty rate of an area in Java Island is influenced by the type of work of the head of the household and internet accessibility in the same location, as well as by the poverty rate of its neighboring region and other explanatory variables.

2. The internet accessibility factor affects the poverty rate in Java Island. The high level of internet accessibility in Java leads to the reduction of poverty rate.

We recommend that the government as a public policymaker increase public access to the internet and target these public policies according to regional characteristics (spatial aspects) to address inequalities in internet access. In narrowing the internet accessibility gap, we recommend equitable connectivity and providing high-speed internet, especially in isolated areas. An effort to equalize internet connectivity can be done by building internet 
kiosks in each village. In addition, public policies are needed to reduce the price of internet connectivity by promoting competition among service providers.

This research still has limitations from various angles which may later be followed up by using panel data through a spatial regression model. It is hoped that further research on spatial poverty will be richer and mutually beneficial, which the government can use to make policies in poverty reduction in Indonesia.

\section{Appendices}

Chart 1. Development of Poverty rate in Java Island, National and RPJMN Target (\%) for 2014-2019

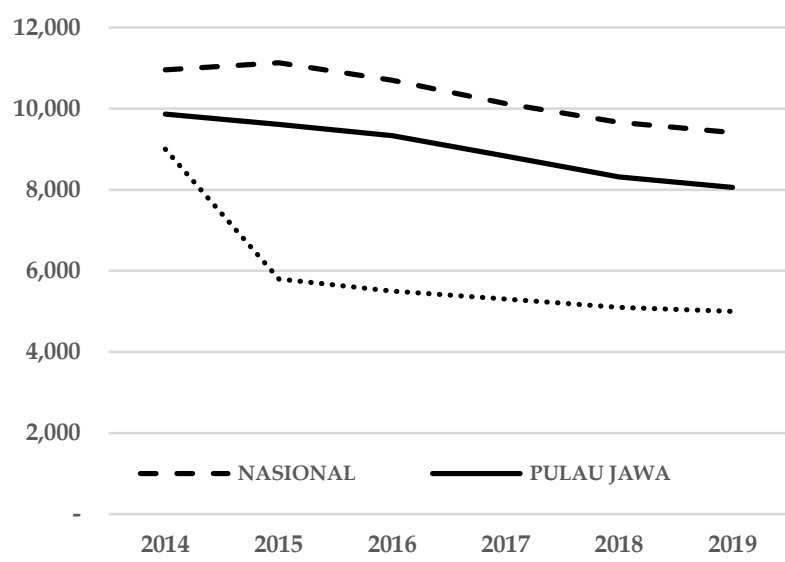

Source: the Central Statistics Agency (BPS), 2020 (processed)

Chart 2. Population Development in Java and National (in thousands) in 2010 - 2019

300000,00

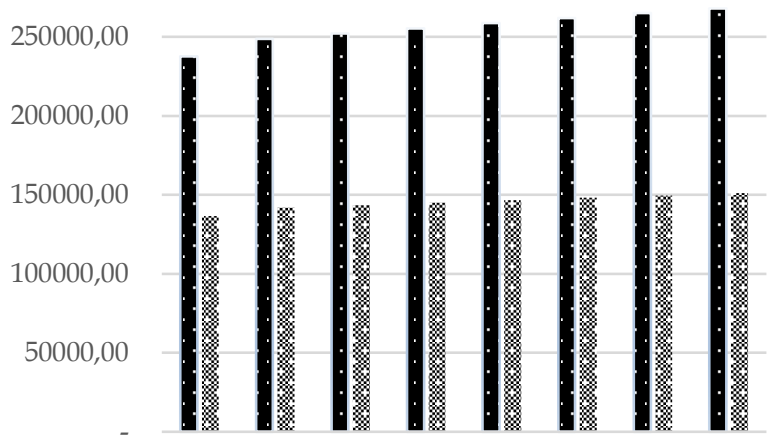

20102013201420152016201720182019 - NASIONAL PULAU JAWA

Source: the Central Statistics Agency (BPS), 2020 (processed)

\section{Chart 3. Correlation of Java and National Poverty Rates (\%) in 2011-2019}

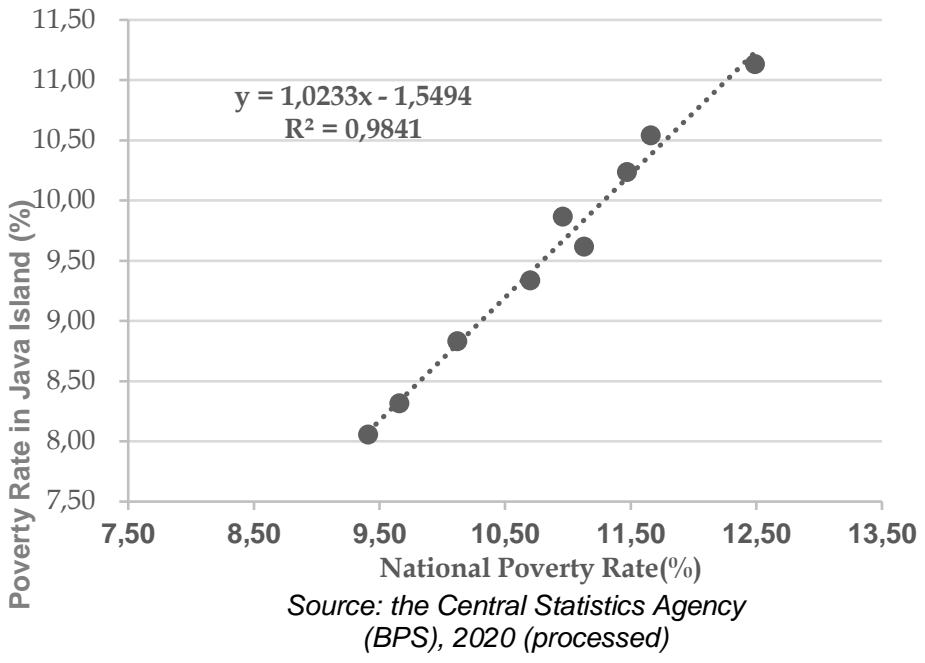

Table 1. Variables Used in Research

\begin{tabular}{|c|c|c|c|}
\hline Variable & Definition & Size & Unit \\
\hline \multicolumn{4}{|c|}{ Response Variable: } \\
\hline $\begin{array}{l}\text { Poverty } \\
\text { (Pov) }\end{array}$ & $\begin{array}{l}\text { Poverty Rate } \\
\text { Percentage } \\
\text { Predictor Variable: }\end{array}$ & Ratio & $(\%)$ \\
\hline $\begin{array}{l}\text { Head of } \\
\text { Household } \\
\text { Education Level } \\
\text { (Edu HHH) }\end{array}$ & $\begin{array}{l}\text { Average length of } \\
\text { schooling of head of } \\
\text { household }\end{array}$ & Ratio & (year) \\
\hline $\begin{array}{l}\text { Head of } \\
\text { Household Type }\end{array}$ & $\begin{array}{l}\text { The average type of } \\
\text { work of head of }\end{array}$ & Ratio & (\%) \\
\hline $\begin{array}{l}\text { of Work } \\
\left(J o b \_H H H\right)\end{array}$ & $\begin{array}{l}\text { household who works in } \\
\text { agriculture in general } \\
\text { (food crops, horticulture, } \\
\text { plantations, animal } \\
\text { husbandry, fisheries, } \\
\text { forestry) }\end{array}$ & & \\
\hline $\begin{array}{l}\text { Household Size } \\
(\text { Size_HH) }\end{array}$ & $\begin{array}{l}\text { Average number of } \\
\text { members in each } \\
\text { household }\end{array}$ & Ratio & $\begin{array}{l}\text { (perso } \\
\mathrm{n})\end{array}$ \\
\hline $\begin{array}{l}\text { Internet } \\
\text { accessibility } \\
\left(A c c \_N e t\right)\end{array}$ & $\begin{array}{l}\text { Average number of } \\
\text { internet users }\end{array}$ & Ratio & $(\%)$ \\
\hline $\begin{array}{l}\text { People's } \\
\text { Business Credit } \\
\text { Accessibility } \\
\left(A c c \_K U R\right)\end{array}$ & $\begin{array}{l}\text { Average number of } \\
\text { People's } \\
\text { Credit users (KUR) }\end{array}$ & Ratio & (\%) \\
\hline
\end{tabular}


Hidayat, Andhy, Prasetyia, Ferry \& Pangestuty, Farah

Table 2. Descriptive Statistics Results

\begin{tabular}{|c|c|c|c|c|c|}
\hline $\begin{array}{c}\text { Varia } \\
\text { ble }\end{array}$ & $\begin{array}{l}\text { Obser } \\
\text { vation }\end{array}$ & $\begin{array}{c}\text { Mea } \\
\text { n }\end{array}$ & $\begin{array}{l}\text { Std. } \\
\text { Dev }\end{array}$ & Min & Max \\
\hline Pov & 119 & $\begin{array}{c}9.623 \\
109\end{array}$ & $\begin{array}{c}4.210 \\
582\end{array}$ & $\begin{array}{c}1.68 \\
\text { (Tang } \\
\text { erang } \\
\text { Selata } \\
\text { n City) }\end{array}$ & $\begin{array}{c}21.21 \\
\text { (Samp } \\
\text { ang } \\
\text { Regenc } \\
\text { y) }\end{array}$ \\
\hline $\begin{array}{l}E d u \\
H H H\end{array}$ & 119 & $\begin{array}{c}7.274 \\
558\end{array}$ & $\begin{array}{c}1.754 \\
733\end{array}$ & $\begin{array}{c}3.211 \\
842 \\
\text { (Sam } \\
\text { pang } \\
\text { Rege } \\
\text { ncy) }\end{array}$ & $\begin{array}{c}11.176 \\
71 \\
\text { (Jakart } \\
\text { a } \\
\text { Selatan } \\
\text { City) }\end{array}$ \\
\hline $\begin{array}{l}\text { Job } \\
H H \bar{H}\end{array}$ & 119 & $\begin{array}{c}25.57 \\
229\end{array}$ & $\begin{array}{c}17.26 \\
217\end{array}$ & $\begin{array}{c}0.204 \\
2901 \\
\text { (Jakar } \\
\text { ta } \\
\text { Selata } \\
\text { n City) }\end{array}$ & $\begin{array}{c}60.147 \\
06 \\
\text { (Pacita } \\
n \\
\text { Regenc } \\
\text { y) }\end{array}$ \\
\hline $\begin{array}{c}\text { Size } \\
\_H H\end{array}$ & 119 & $\begin{array}{c}3.533 \\
624\end{array}$ & $\begin{array}{l}0.245 \\
4073\end{array}$ & $\begin{array}{c}2.863 \\
429 \\
\text { (Yogy } \\
\text { akarta } \\
\text { City) }\end{array}$ & $\begin{array}{c}4.4045 \\
45 \\
\text { (Seran } \\
\text { g City) }\end{array}$ \\
\hline $\begin{array}{c}A c c \\
N e t\end{array}$ & 119 & $\begin{array}{c}46.04 \\
493\end{array}$ & $\begin{array}{c}11.88 \\
116\end{array}$ & $\begin{array}{c}26.83 \\
012 \\
\text { (Luma } \\
\text { jang } \\
\text { Rege } \\
\text { ncy) }\end{array}$ & $\begin{array}{c}73.476 \\
92 \\
\text { (Tange } \\
\text { rang } \\
\text { Selatan } \\
\text { City) }\end{array}$ \\
\hline $\begin{array}{l}A c c \\
K \cup \bar{R}\end{array}$ & 119 & $\begin{array}{c}8.467 \\
903\end{array}$ & $\begin{array}{c}4.498 \\
701\end{array}$ & $\begin{array}{c}0.076 \\
1905 \\
\text { (Jakar } \\
\text { ta } \\
\text { Pusat } \\
\text { City) }\end{array}$ & $\begin{array}{c}18.880 \\
15 \\
\text { (Panga } \\
\text { ndaran } \\
\text { Regenc } \\
\text { y) }\end{array}$ \\
\hline
\end{tabular}

Source: Susenas 2018 (processed)

Table 3. Autocorrelation Test Results

(Moran I)

\begin{tabular}{|c|c|c|c|}
\hline \multirow[t]{2}{*}{ Variable } & \multicolumn{2}{|c|}{ Spatial Weight } & \multirow[t]{2}{*}{ Sign. } \\
\hline & $\begin{array}{c}\text { Moran I } \\
\text { value }\end{array}$ & $p$-value & \\
\hline Pov & 0.4558 & $\begin{array}{c}2.403 e- \\
12\end{array}$ & $(* * *)$ \\
\hline Edu_HHH & 0.4963 & $\begin{array}{c}3.193 e- \\
14\end{array}$ & $(* * *)$ \\
\hline Job_HHH & 0.4462 & $8.09 e-12$ & $(* * *)$ \\
\hline Size_HH & 0.6030 & $<2.2 \mathrm{e}-16$ & $(* * *)$ \\
\hline
\end{tabular}

\begin{tabular}{|c|c|c|c|}
\hline Acc_Net & 0.5348 & $\begin{array}{c}3.531 \mathrm{e}- \\
16\end{array}$ & $(* * *)$ \\
\hline Acc_KUR & 0.6930 & $<2.2 \mathrm{e}-16$ & $(* * *)$ \\
\hline
\end{tabular}

Tabel 4. Hasil Pengujian Lagrange Multiplier (LM)

\begin{tabular}{|c|c|c|c|}
\hline \multirow{2}{*}{$\begin{array}{c}\text { Lagrange } \\
\text { Multiplier } \\
\text { Test }\end{array}$} & \multicolumn{2}{|c|}{ Spatial Weight } & \multirow[t]{2}{*}{ Sign. } \\
\hline & Value & $p$-value & \\
\hline $\begin{array}{l}\text { Lagrange } \\
\text { Multiplier Lag } \\
\text { (LM Lag) }\end{array}$ & 11.798 & 0.0005928 & $(* * *)$ \\
\hline $\begin{array}{l}\text { Lagrange } \\
\text { Multiplier } \\
\text { Error (LM } \\
\text { Error) }\end{array}$ & 15.306 & $9.142 \mathrm{e}-05$ & $(* * *)$ \\
\hline $\begin{array}{l}\text { Robust } \\
\text { Lagrange } \\
\text { Multiplier Lag } \\
\text { (RLM Lag) }\end{array}$ & 0.2140 & 0.6436 & \\
\hline $\begin{array}{l}\text { Robust } \\
\text { Lagrange } \\
\text { Multiplier } \\
\text { Error (LM } \\
\text { Error) } \\
\end{array}$ & 3.7218 & 0.05371 & $(*)$ \\
\hline
\end{tabular}


Role of Internet Accessibility in Reducing the Poverty rates in Java; a Spatial Approach

Table 5. Best Model Selection Source: Susenas 2018 (processed)

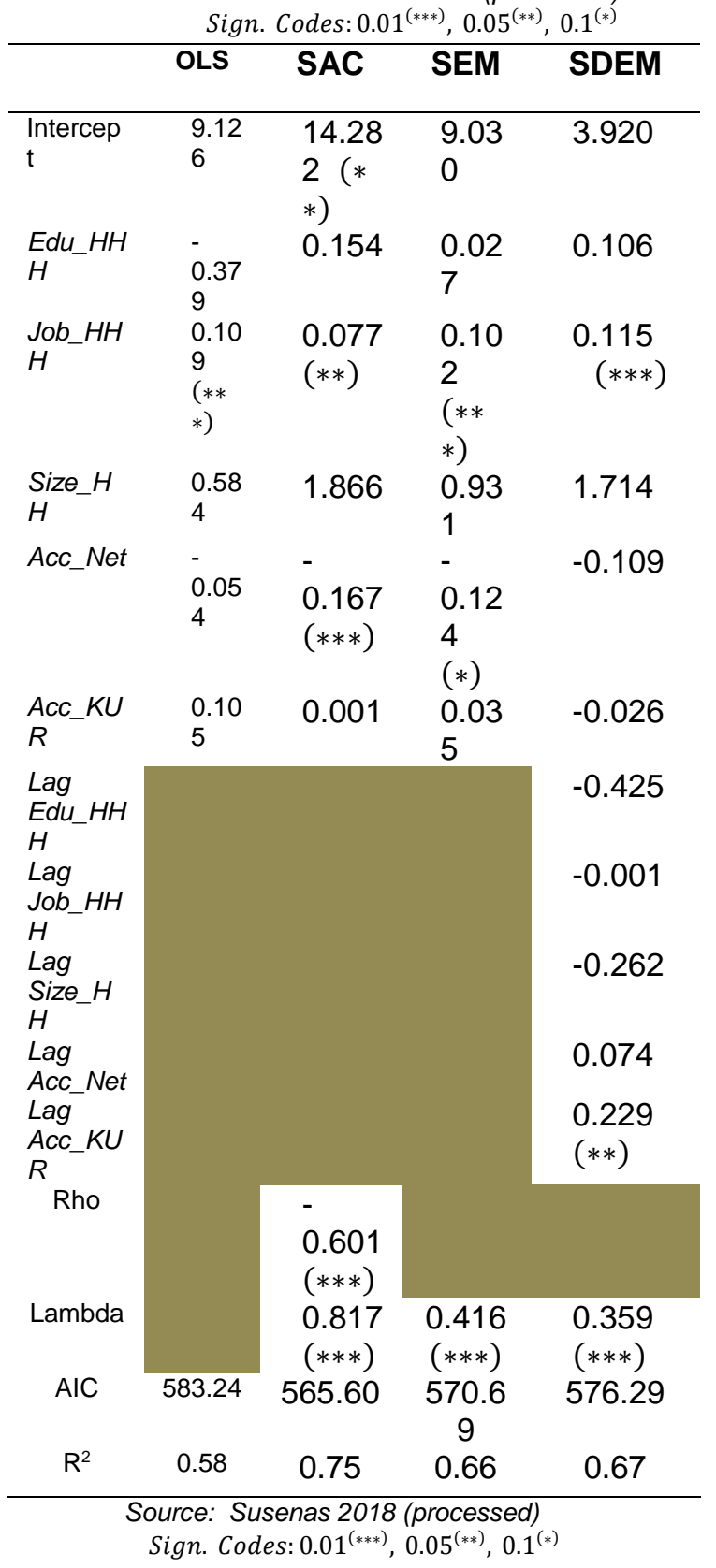

Figure 1. Poverty Rates in Java Island in 2018

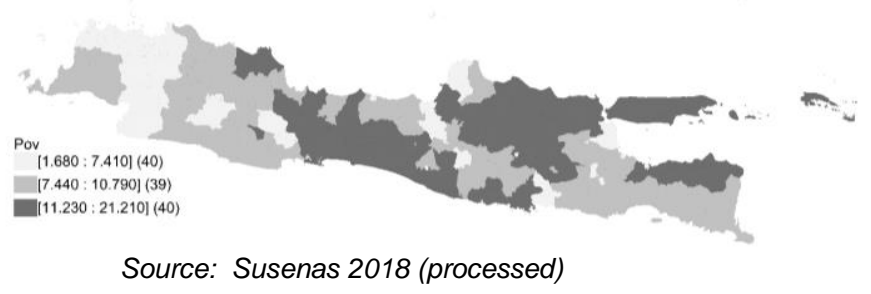

Figure 2. Internet Accessibility Level in Java Island in 2018

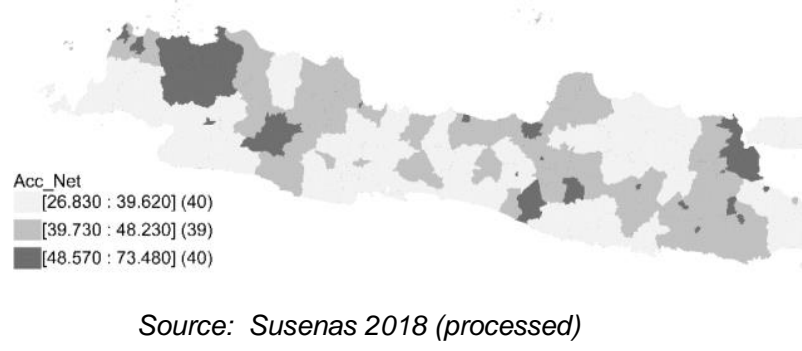

Figure 3. Comparison of Internet Accessibility Levels of

Poor and Non-Poor Population (\%) in Java Island in 2018

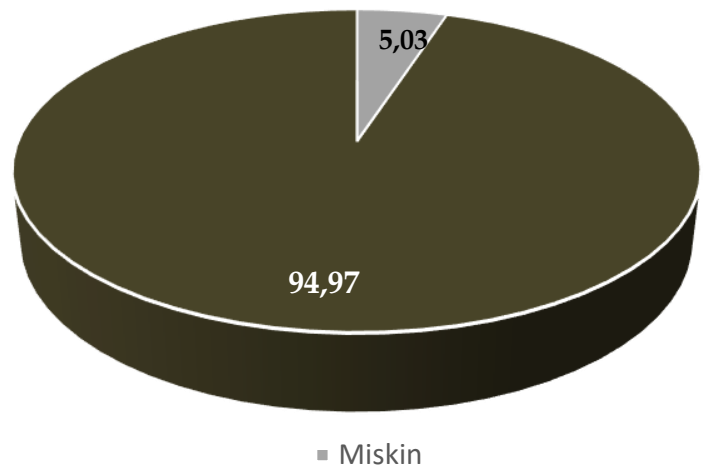

Source: Susenas 2018 (processed) 


\section{References}

Ahlström, A., Pilesjö, P., \& Lindberg, J. (2011). Improved accessibility modeling and its relation to poverty e A case study in Southern Sri Lanka. Habitat International, 35(2), 316-326.

Alderete, M. V. (2019). Examining the drivers of internet use among the poor: The case of Bahía Blanca city in Argentina. Technology in Society, 59, 42-58.

Alfrojems, \& Anugrahini, T. (2019). Pengentasan Kemiskinan Perdesaan melalui Pengembangan Ekonomi Kreatif, Pariwisata dan Modal Sosial. Sosio Informa, 5(2), 113-127.

Anselin, L. (1988). Spatial Econometrics: Methods And Models. Kluwer academic.

Azzasyofia, M., \& Adi, I. R. (2017). Pembangunan Sosial Pedesaan Melalui Pemanfaatan Teknologi Informasi Dan Komunikasi (TIK). Journal of Social Welfare, 18(2), 139-149.

Bappenas. (2018). Analisis Wilayah dengan Kemiskinan Tinggi (Pertama; V. Yulaswati, ed.). Jakarta: Kedeputian Bidang Kependudukan dan Ketenagakerjaan Kementerian PPN/ Bappenas.

Benevenuto, R., \& Caulfield, B. (2020). Measuring Access To Urban Centres In Rural Northeast Brazil: A Spatial Accessibility Poverty Index. Journal of Transport Geography, 82(1), 1-15.

BPS. (2007). Statistik Indonesia 2007. Jakarta: Badan Pusat Statistik.

BPS. (2016). Ringkasan Eksekutif Pengeluaran dan Konsumsi Penduduk Indonesia. Jakarta: Bdan Pusat Statistik.

BPS. (2019). Statistik Indonesia 2019. Jakarta: Badan Pusat Statistik.

Chambers, R. (1983). Rural Development: Putting The Last First (1st ed.). London: Longman.

Choshin, M., \& Ghaffari, A. (2017). An investigation of the impact of effective factors on the success of e-commerce in small-and medium-sized companies. Computers in Human Behavior, 66, 67-74.

Cobbinah, P. B., \& Black, R. (2013). Dynamics of Poverty in Developing Countries: Review of Poverty Reduction Approaches. Journal of Sustainable Development, 06(09).

Crandall, M. S., \& Weber, B. A. (2004). Local Social and Economic Conditions, Spatial Concentrations of Poverty, and Poverty Dynamics. American Journal of Agricultural Economics, 86(5), 1276-1281.

Deursen, A. J. A. M. Van, \& Dijk, J. A. G. M. Van. (2019). The first-level digital divide shifts from inequalities in physical access to inequalities in material access. New Media \& Society, 21(2), 354-375.

Dhahri, S., \& Omr, A. (2020). Foreign capital towards SDGs 1 \& 2-Ending Poverty and hunger: The role of agricultural production. Structural Change and Economic Dynamics, 53(1), 208-221.

Doong, S. H., \& Ho, S. C. (2012). The Impact of ICT Development on The Global Digital Divide. Electronic Commerce Research and Applications, 11, 518-533.

Draper, N. R., \& Smith, H. (1998). Applied Regression Analysis (3rd ed.). Canada: John Wiley \& Sons, Inc.

Elhorst, J. P. (2014). Spatial Econometrics: From Cross-Sectional Data to Spatial Panel $(\mathrm{H}$. Folmer, M. Partridge, G. Duranton, D. P. McMillan, A. Rodríguez-Pose, \& H. W. C. Yeung, eds.). Dordrecht: Springer Griefs ini Regional Science.

Fitriani, R., \& Efendi, A. (2019). Ekonometrika Spasial Terapan dengan $R$ (Pertama). Malang: UB Press.

Flanagin, A. J., \& Metzger, M. J. (2001). Internet use in the contemporary media environment. Human Communication Research, 27(1), 153-181.

Galperin, H. (2017). Why Are Half of Latin Americans Not Online? A Four-Country Study of Reasons for Internet Nonadoption. International Journal of Communication, 11, 3332-3354.

Hasibuan, S. N., Juanda, B., \& Mulatsih, S. (2019). Analisa Sebaran dan Faktor Penyebab Kemiskinan di Bandung Barat. Jurnal Agribisnis Indonesia, 7(2), 79-91.

Haughton, J., \& Khandker, S. R. (2009). Handbook on Poverty and Inequality. Washington DC: World Bank Publications.

Haughton, J., \& Khandker, S. R. (2012). Pedoman tentang Kemiskinan dan Ketimpangan (Pertama; M. Y. Gultom, ed.). Jakarta: Salemba Empat.

Khan, M. M., Hotchkiss, D. R., Berruti, A. S. A., \& Hutchinson, P. L. (2006). Geographic aspects of poverty and health in Tanzania: does living in a poor area matter? Health Policy and Planning, 21(2), 110-122.

Khoirunnisa, \& Budiarti, W. (2019). Pengaruh Teknologi Informasi Dan Komunikasi Terhadap Tingkat Kemiskinan Di Indonesia Tahun 2012-2017 (No. 1). https://doi.org/https://doi.org/10.34123/se mnasoffstat.v2019i1

Kuncoro, M. (2006). Ekonomika Pembangunan, Teori, Masalah, dan Kebijakan (4th ed.). Yogyakarta: UPP AMP YKPN.

Lampert, M., \& Papadongonas, P. (2016). 


\section{Role of Internet Accessibility in Reducing the Poverty rates in Java; a Spatial Approach}

Towards 2030 Without Poverty. Amsterdam: Glocalities: think global, act local.

Lin, J., Yu, Z., Wei, Y. D., \& Wang, M. (2017). Internet Access, Spillover and Regional Development in China. Sustainability, 9(6), 946.

Litan, R. E., \& Rivlin, A. M. (2001). Projecting the Economic Impact of the Internet. American Economic Review, 91(2), 313-317.

Lucas, K., Mattioli, G., Verlinghieri, E., \& Guzman, A. (2016). Transport poverty and its adverse social consequences. Proceedings of the Institution of Civil Engineers-Transport, 169(6), 353-365.

Maurseth, P. B. (2018). The effect of the Internet on economic growth: Counter-evidence from cross-country panel data. Economics Letters, 172, 74-77.

Park, S. (2017). Digital Inequalities in Rural Australia: A Double Jeopardy of Remoteness and Social Exclusion. Journal of Rural Studies, 54, 399-407.

Risner, C., \& Gadhavi, V. (2015). Using Realtime Monitoring to Enhance Graduation from Extreme Poverty in Bangladesh. IDS Bulletin, 46(2), 115-123.

Rivera, J. M., \& Mora, F. G. (2020). Internet access and poverty reduction: Evidence from rural and urban Mexico. Telecommunications Policy, 45(2), 102076.

https://doi.org/https://doi.org/10.1016/j.telp ol.2020.102076 Received 9 May 2020; Received in revised form 1

Ruhyana, N. F., \& Essa, W. Y. (2020). Opportunities of Using Information and Communication Technology in Reducing Poverty. JEJAK: Jurnal Ekonomi Dan Kebijakan, 13(2), 319-329.

Rupasingha, A., \& Goetz, S. J. (2003). The Causes of Enduring Poverty An Expanded Spatial Analysis of the Structural Determinants of Poverty in the US. In Rural Development Paper (No. 22). The Pennsylvania State University.

Sen, A. (1985). A Sosiological Approach to the Measurement of Poverty: a Reply to Professor Peter Townsend. Oxford Economic Papers, 37(4), 669-676.

Setiyani, R. (2010). Pemanfaatan Internet Sebagai Sumber Belajar. Jurnal Pendidikan Ekonomi Dinamika Pendidikan, 5(2), $117-133$.

Silvana, H., Rullyana, G., \& Hadiapurwa, A. (2019). Kebutuhan Informasi Guru Di Era Digital: Studi Kasus Di Sekolah Dasar Labschool Universitas Pendidikan Indonesia. Jurnal Dokumentasi Dan
Informasi, 40(2), 147-158.

Sujarwoto, \& Tampubolon, G. (2016). Spatial inequality and the Internet divide in Indonesia 2010-2012. Telecommunications Policy, 40(7), 602616.

Tisdell, C. (2017). Information technology's impacts on productivity and welfare: a review. International Journal of Social Economics, 44(3), 400-413.

Wardhana, A., Kharisma, B., \& Lisdiyanti, T. (2020). Teknologi Informasi Komunikasi Dan Pertumbuhan Ekonomi Wilayah Barat Dan Timur Indonesia Periode 2014-2018. E-Jurnal Ekonomi Dan Bisnis Universitas Udayana, 9(11), 1103-1116.

Widiastuti, T. (2014). Kemiskinan Struktural Informasi. Jurnal IImu Komunikasi., 8(3), 314-329.

World Bank. (2003). ICT and MDGs: a world bank group persepective. Washington DC: World Bank Publications.

World Bank. (2018). Berinvestasi dalam Peluang Mengakhiri Kemiskinan. https://doi.org/10.1596/978-1-4648-1302-3

Yekini, Rufai, M., Adetoba, B., Akinwole, A., \& Ojo, O. (2012). ICT Tools for Poverty Eradication and Economic Growth in Nigeria. Greener Journal of Educational Research, 2(1), 013-019. 